\title{
Josef Pieper i John Henry Newman o neformalnoj sigurnosti vjere*
}

\author{
ŠIMo ŠOKČEVIĆ* \\ • https://doi.org/10.31823/d.27.1.4 • \\ UDK: 1 Pieper, J.*27-184.3 Newman, J.H. • Izvorni znanstveni rad \\ Primljeno: 23. listopada 2018. • Prihvaćeno: 12. ožujka 2019.
}

${ }^{*}$ Izv. prof. dr. sc.

Šimo Šokčević,

Katolički bogoslovni

fakultet u Đakovu

Sveučilišta J.J.

Strossmayera u Osijeku,

P. Preradovića 17,

p. p. 54, 31400 Đakovo,

Hrvatska,

simo.sokcevic@djkbf.hr

Sažetak: Ovaj članak svojevrstan je pokušaj tumačenja Pieperove filozofske rasprave $\mathrm{O}$ vjeri uz pomoć Newmanovih promišljanja s obzirom na to da se Pieper u svojoj raspravi referira na pojedine Newmanove teze, no ne ulazi u njihovu dubinu. Osim usporedbe te dvojice autora u kontekstu filozofskoga tematiziranja vjere, ovaj rad ima za cilj pokazati da ispravno shvaćena vjera sadrži kapacitet da pruži ono što je čovjeku danas najpotrebnije, i u osobnom i u društvenom kontekstu, a to je sigurnost. S tim ciljem članak u četirima dijelovima prikazuje značenje vjere, aspekte neformalne sigurnosti vjere i moralnih predispozicija koje su nužne za življenje osobne vjere u općespoznajnom i religioznom obliku. U tome smislu ljubav se nameće kao zaključni imperativ - temeljna moralna predispozicija koja štiti vjeru od svih zlouporaba, oblikuje ju, daje joj konzistentnost, usmjerenje i vodi ju prema istini.

Ključne riječi: Josef Pieper, John Henry Newman, vjera, razum, sigurnost, moralne predispozicije, ljubav.

\footnotetext{
* Autor članka, ujedno i glavni urednik časopisa Diacovensia, zbog mogućega sukoba interesa izuzet je iz procesa evaluacije ovoga članka te prihvaćanja i odlučivanja o njegovu objavljivanju. Članak je nastao na tragu predavanja koje je autor održao na znanstvenom kolokviju prigodom 20 godina od smrti njemačkoga filozofa Josefa Piepera koji je održan u Đakovu u organizaciji Katoličkoga bogoslovnoga fakulteta u Đakovu 5. travnja 2017. godine. Svi sudionici toga skupa obvezali su se objaviti svoje radove u ovom časopisu. (Zapisnik sjednice Uredničkoga vijeća časopisa Diacovensia - Klasa: 612-10/19-01/02 Ur. broj: 2121-32-01-19-02)
} 


\section{Uvod}

Danas je gotovo na razini dogme važno držati do $S T E M^{1}$ obrazovanja i istraživanja koja se primarno zasnivaju na razumu i empiriji. Nije sporno da su takva istraživanja vrlo važna i da se zasnivaju na znanstvenoj egzaktnosti koja je jamac sigurnosti. No pogrješno je to što se takav pristup obrazovanju i istraživanju smatra apsolutno sigurnim i nepobitnim, nečim do čega univerzalno treba držati, poput dogme, dok se drugi pristupi percipiraju kao upitni i nesigurni. Ako je uistinu držanje do STEM istraživanja u današnje vrijeme podignuto na razinu dogme, onda ta teza koju smo izrekli u prethodnoj rečenici zapravo predstavlja herezu takvomu uvjerenju.

Međutim, s obzirom na to da smatramo kako je pogrješno ta istraživanja misliti kao dogmu, ne doživljavamo posebno važnom optužbu koja će okvalificirati suprotstavljanje takvomu mišljenju kao nešto što je u sebi heretično. Štoviše, smatramo da, iako se STEM istraživanja neizravno tiču svih nas, ona su, zapravo, izravno rezervirana tek za jedan manji broj ljudi. Za većinu svjetske populacije život je, kako ističe

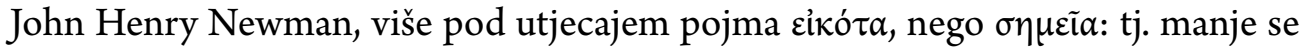
zasniva na dokazu, a više na prethodno razmatranim načelima, pogledima i željama koji su ključni u kontekstu vjere. ${ }^{2}$ No ne treba kriti mišljenje da se u pozadini takvih negativnih stavova prema vjeri često kriju krive, ako ne i opasne filozofije.

$S$ druge strane suvremeni svijet suočava se s permanentnom prijetnjom terorizma, gdje se mnoga zla čine u ime (religiozne) vjere. Profili terorista ne ukazuju na to da je uvijek riječ o psihopatologijii, već da je riječ o razumnim ljudima koji u određenom razdoblju smatraju da je terorizam najučinkovitiji način da se ostvare određeni ciljevi. ${ }^{3}$ Psiholozi će danas pronaći mnoštvo razloga zašto je netko zao, pa će im takvi ljudi proći ispod radara, no filozofija itekako prepoznaje takav oblik (raz)uma i kategorizira ga kao bolesnoga, kao zlo. ${ }^{4}$ Ubojstvo desetaka, stotina ljudi ili samo

\footnotetext{
${ }^{1}$ Pojam STEM-a teško je prenijeti u duh hrvatskoga jezika. Riječ je o engleskom akronimu koji je satkan od početnih slova četiriju područja: science, technology, engineering i mathematics. Usp. http:// www.livescience.com/43296-what-is-stem-education.html (8. 6. 2017.)

2 »Tako svakodnevno do nas dolaze različite informacije s ulice ili iz medija. Mi nemamo dokaza za pojedine događaje, ne znamo svjedoke ili bilo što o njima, te ponekad vjerujemo implicitno, a ponekad ne; nekada povjerujemo bez da tražimo dokaz, a nekada ne vjerujemo sve dok ne dobijemo dokaze. Npr. ako se pojavi glasina o razornom potresu u Siriji ili na jugu Europe, trebali bismo spremno povjerovati tomu jer vrlo vjerojatno to može biti istina i nema neke posljedice po nas. Ako se nešto događa nama u blizini onda provjeravamo je li događaj autentičan.« J. H. NEWMAN, Fifteen Sermons Preached before the University of Oxford, University of Notre Dame, 1997., X., br. 27 (= OUS).

${ }^{3}$ Usp. Š. ŠOKČEVIĆ, Suvremeni terorizmi, u: Svjetlo riječi (2016.)9, 20-22.

${ }^{4}$ Psiholozima ni Hitler nije bio zao. Usp. L. F. H. SVENSEN, Filozofija zla, Beograd, 2006., 20.
} 
jednoga čovjeka zbog vjerskih ideala čin je bolesnoga, izopačenoga (raz)uma, koji nije privilegij samo jednoga naroda ili vjerske skupine, već je to općeljudska pojava. Zbog tih razloga čini se da je danas više nego ikada prije potrebno filozofski i na ispravnim temeljima promišljati vjeru, ali i sigurnost vjerske spoznaje. Jedan je od onih koji su uvidjeli važnost ispravnoga tematiziranja vjere na filozofskim temeljima i poznati njemački filozof Josef Pieper. Njegova rasprava $O$ vjeri važan je filozofski tekst koji je pod snažnim utjecajem Tome Akvinskoga, ali i brojnih drugih kršćanskih mislilaca, poput Johna Henryja Newmana.

Stoga je prvi cilj ovoga članka usporedba filozofskoga promišljanja vjere dvojice filozofa Piepera i Newmana koji su prema našemu mišljenju ispravno tematizirali problematiku vjere s filozofske točke gledišta i time podsjetili na važnost vjerske spoznaje, često osporavane danas, ali i u proteklim stoljećima. ${ }^{5}$ Pieperove i Newmanove izvode ponajprije uspoređujemo iz perspektive filozofije spoznaje i filozofijske teologije. To radimo ne samo zato da bismo vidjeli kako su Pieper i Newman odgovarali na pojedinačna pitanja u kontekstu vjere (što, dakako, ne ćemo moći u potpunosti izbjeći) nego, zapravo, ovom analizom želimo doći do uravnoteženoga i integrirajućega filozofskoga pristupa i vjeri u općespoznajnome smislu (što je predmet istraživanja filozofije spoznaje) i religioznoj (katoličkoj) vjeri (što je područje filozofijske teologije). Komparacijom Piepera i Newmana dolazimo do drugoga cilja ovoga rada kojim želimo pokazati da u današnjem dobu, koje prati kriza sigurnosti, na ispravan način shvaćena vjera predstavlja sigurnu luku ljudskoga života.

Da bismo ostvarili navedene ciljeve, članak smo podijelili u četiri osnovna dijela i u njemu djelomično slijedimo strukturu Pieperove rasprave $O$ vjeri koju opširnije tumačimo Newmanovim promišljanjima. U prvome dijelu kratko se referiramo na to što uopće znači vjerovati. $U$ drugome dijelu propitkujemo sigurnost vjerske spoznaje, u trećem istražujemo zašto su i koje su moralne predispozicije važne za vjeru te na kraju, $\mathrm{u}$ četvrtome dijelu rada analiziramo sigurnost religiozne (katoličke) vjere.

\footnotetext{
${ }^{5}$ Pieper i Newman živjeli su u različitim razdobljima, no Newman je nesumnjivo utjecao na Pieperovu filozofsko-teološku misao jer analizom njegovih djela možemo uočiti da se on ne samo usputno referira nego i izričito cijeni Newmanova promišljanja iz područja filozofije spoznaje, filozofije obrazovanja te napose filozofske teologije, triju područja kojima se Newman ponajviše bavio. Tako npr. možemo vidjeti u djelima Was heißt philosophieren i Mißbrauch der Sprache, Mißbrauch der Macht da se Pieper referira na Newmanov pojam »slobodnoga, džentlmenskog znanja «. Usp. J. PIEPER, Was heisst philosophieren, München, 1948. i J. PIEPER, Mißbrauch der Sprache, Mißbrauch der Macht, Ostfildern bei Stuttgart, 1988. S druge strane velika je zasluga Piepera koji je vrijednu Newmanovu misao prenio na njemačko govorno područje jer je on do tada bio prilično nepoznat na tom području, a često i krivo prevođen, kako uviđa i sam Pieper. Usp. J. PIEPER, O vjeri, Zagreb, 2012., 36 .
} 


\section{1. Što znači vjerovati?}

Pieper i Newman dijele ista polazišta. Kao i svi veliki umovi, polaze od onoga što nam je dano. U okvirima glavne teme ovoga rada to je vjera u općem smislu ili što uopće znači vjerovati. Za Piepera $\gg$ vjera uvijek znači nekomu nešto vjerovati $<^{6}$ Važna je suglasnost s osobom i nebjelodanim objektivnim sadržajem. Suglasnost počiva i na tome što onaj koji vjeruje $\gg$ nema posla samo s nekim objektivnim sadržajem, kao primjerice onaj tko zna, nego istodobno is Nekim, naime sa svjedokom koji jamči za objektivni sadržaj i na kojega se onaj koji vjeruje oslanja «. ${ }^{7}$ Taj odnos treba shvaćati povezano. Također odnos čovjek - čovjek ne može zahtijevati vjeru u strogome smislu, kako smo naveli, već u tome smislu ono se mora odnositi na biće koje je $\gg$ neusporedivo više iznad punoljetnih ljudi $\ll$ i jedino je tada vjera naravna čovjeku, $\gg$ primjerena njegovu dostojanstvu i ograničenosti $\ll{ }^{8}$ To shvaćanje vidimo i kod Newmana potpuno jednako izraženo kao i kod Piepera. Također pitanje suglasnosti osobe i objektivnoga sadržaja nešto je što je snažno apostrofirano kod Newmana i u njegovim Oxford University Sermons i u najpoznatijem filozofskom djelu An Essay in Aid of a Grammar of Assent. ${ }^{9}$ Prema tomu vidimo da Newman i Pieper na jednak način percipiraju vjeru, no postavlja se pitanje njezine sigurnosti.

\section{Sigurnost vjerske spoznaje}

Za Newmana vjera ne proizlazi izravno iz razuma, ali istine vjere kompatibilne su $s$ razumom i sam čin vjere doživljava se kao racionalan čin. Prema njemu vjera ima odgovornost prema razumu. Ona mora imati mogućnost da ju se može opravdati razumom. Upravo zato razum provjerava i verificira vjeru te igra važnu kritičku ulogu, no ne i kreativnu kada je vjera u pitanju. Vjera mora biti razumljiva i mora biti opravdana razumom, ali ne na način da je ovisna o njemu. Kako primjećuju i Pieper i Newman, vjera ima svoju autonomiju i može djelovati potpuno neovisno o razumu. No što je to što tako shvaćenoj vjeri daje sigurnost?

${ }^{6} \mathrm{~J}$. PIEPER, O vjeri, 19.

${ }^{7}$ Isto, 16.

${ }^{8}$ Svaki drugi oblik vjere koji bismo zahtijevali od čovjeka bio bi protivan njegovoj naravi. Mi u strogom smislu možemo vjerovati samo osobi koja nadilazi ljudska bića, samo Bogu. Usp. isto, 24.

${ }^{9}$ Kod Newmana naglašavanje te suglasnosti vidljivo je u kontekstu njegove borbe protiv agresivnoga liberalizma, koji Newman naziva antidogmatskim principom. Upravo Newmanova želja da poveže osobni element vjere i dogmatski sadržaj bitna je za njegovo razumijevanje katoličke vjere, u tome što on smatra da dogma kao objektivni sadržaj i osobni element vjere nisu u suprotnosti, nego su međusobno usko povezani. Usp. W. WARD, The Life of John Henry Cardinal Newman, II, London, 1912., 459-462. (Newmanov nastupni kardinalski govor). 


\subsection{SiguRNOST I NEMIR MIŠLJENJA}

Prema Pieperu vjera zahtijeva razumijevanje, shvaćanje i njezina suglasnost na tome počiva. Pozivajući se na Tomu, Pieper kaže: »Čovjek ne bi mogao dati suglasnost nijednom članku vjere kada ga na neki način ne bi razumio. $\ll{ }^{10}$ Prema tomu razumijevanje je izvor sigurnosti. No također onaj »kome vjerujem mora sam od sebe znati ono što na način vjere prihvaćam kao istinu $\ll .{ }^{11}$ Pieper smatra da $\gg$ praeambula fidei « - pretpostavke vjere nisu ono što vjernik vjeruje, one pripadaju onomu što on zna ili što u najmanju ruku mora moći znati. ${ }^{12}$

Tu nije riječ samo o običnom dojmu, nego o pravoj spoznaji koja se ostvaruje u susretu sa zbiljnošću. Izvjesnost ili sigurnost, prema Pieperu, može se definirati na način da se pod njom misli na čvrstu suglasnost koja isključuje svaku sumnju i u tom smislu jasno je da je narav vjere, i to ne samo religiozne, izvjesna. Međutim sigurnost se može definirati i tako da ju se poima kao čvrstu suglasnost koja se temelji na očitosti, bjelodanosti objektivnoga sadržaja. Onoga koji vjeruje prožima sigurnost, ali istovremeno i nesigurnost.

Toma ističe da se u onome koji vjeruje nalazi element savršenosti, ali i nesavršenosti, »savršenost je u čvrstoći suglasnosti «, a nesavršenost se pronalazi $u$ »nemiru mišljenja « (cogitatio). ${ }^{13}$ To je, zapravo, »tragajuće istraživanje, tražeće promišljanje, savjetovanje sa samim sobom, prije odluke, biti na tragu $\ldots \ll^{14}$, reći će Pieper pozivajući se na Tomu. Nesigurnost se, prema Tomi, javlja zbog toga što se čovjek ne kreće po vlastitom, nego po stranom tlu. ${ }^{15}$ Međutim čin vjere cilja na zbiljnost $\mathrm{i}$ on ne zastaje pred nečim rečenim, već pred onim što jest, pred objektivnom stvarnošću, tako da će neki govoriti o spoznaji, znanju, uvidu u tom kontekstu ili govoriti o $\gg$ svjetlu vjere « u kojem se događa da čovjek vidi ono što vjeruje. ${ }^{16}$ Ta sigurnost ili izvjesnost počiva na tome što vjernik ima posla sa svjedokom čiji $\gg$ uvid i istinitost beskonačno nadilaze svaku ljudsku mjeru $\ll .{ }^{17}$

Pitanje sigurnosti glavna je i Newmanova preokupacija u djelu An Essay in Aid of a Grammar of Assent gdje vidimo da se njegova promišljanja u svojim temeljnim postavkama poklapaju s Pieperovim. Međutim Newman mnogo opširnije analizi-

\footnotetext{
${ }^{10} \mathrm{~J}$. PIEPER, O vjeri, 14.

${ }^{11}$ Isto, 36.

${ }^{12}$ Isto, 38.

${ }^{13}$ Isto, 42.

${ }^{14}$ Isto, 43.

${ }^{15}$ Isto, 44.

${ }^{16}$ Isto, 46.

${ }^{17}$ Isto, 47.
} 
ra problematiku sigurnosti vjere od samoga Piepera. Stoga ćemo se sada posvetiti Newmanovu razumijevanju sigurnosti vjere te na taj način pokušati protumačiti Pieperove teze koje smo prethodno iznijeli. No, analizirajući sigurnost vjere kod Newmana, ne ćemo se prvotno baviti djelom An Essay in Aid of a Grammar of Assent. Naš interes bit će primarno usmjeren na njegove Oxford University Sermons koje su prethodile tomu djelu i u velikoj mjeri teško je razumjeti An Essay in Aid of a Grammar of Assent, pa i pitanje sigurnosti vjerske spoznaje, ako nismo upoznati $\mathrm{s}$ tim propovijedima (posebno: $\mathrm{X}-\mathrm{XIV}$ ). U tim propovijedima Newman veliku pozornost pridaje prethodnim vjerojatnostima koje po njegovu mišljenju oblikuju vjeru, daju joj potrebnu sigurnost.

\subsection{Prethodne Vjerojatnosti}

Prethodne vjerojatnosti pretpojmovno su područje razumijevanja koje je bitno za našu percepciju stvarnosti, tj. predstavljaju određene predispozicije u našem svakodnevnom životu i radu gdje Newman uviđa da »naše sklonosti imaju veze s našim uvjerenjima. Gotovo da je postalo poslovica da osobe vjeruju u ono što žele da bude istina. Oni će teško priznati pogrješku svakog njima vrijednog projekta ili pak poslušati glasnika koji im donosi vijest o bolesti $\ll .{ }^{18}$ Newman primjećuje da je potpuno isti slučaj s unaprijed stvorenim mišljenjima o nečem. ${ }^{19}$ Ljudi smjesta povjeruju u nepovoljne informacije vezane za osobe koje im se ne sviđaju ili u potvrde vlastitih teorija. U tom smislu Newman primjećuje da $\gg$ sitnice takve, lake kao zrak « jesu sve ono što predisponirani um zahtijeva za vjerovanje i djelovanje. ${ }^{20}$ Mnoge naše spoznaje i počivaju na tome i ne mogu se opravdati logičkom deduk-

\footnotetext{
${ }^{18}$ OUS, X., br. 29. Na istome mjestu Newman primjećuje »da nas velika želja za objektom ponekad čini nepovjerljivim u to da smo ga ostvarili. Sasvim sigurno to se događa onda kada postignuće smatramo nevjerojatnim, u onolikoj mjeri u kojoj ga smatramo poželjnim «. Stoga Toma sumnja u uskrsnuće, zatim Jakov, nakon što su ga prevarila vlastita djeca, ne vjeruje u to da je Josip upravitelj u Egiptu: »Njegovo se srce skameni jer im nije mogao vjerovati. Ali kad mu ispripovjediše sve što im je Josip rekao i kad vidje kola što ih je Josip poslao da ga prevezu, duh njihova oca Jakova oživje.« (Post 45, 27)

${ }^{19}$ Isto, XII., br. 6. Treba naglasiti da u kontekstu govora o prethodnim vjerojatnostima ne uključuje veliku većinu kršćana koji vjeruju iz pukoga običaja ili tradicije. On smatra da su oni kršćanstvo naslijedili i njihova $\gg$ srca nisu zainteresirana za istinsku religiju «. Kada govori o vjernicima, on govori o ljudima koji $\gg$ ne vjeruju u neke stvari zato što su njihovi očevi vjerovali u to, već imaju vlastitu vjeru i iz toga razloga vjeruju u nešto što se razlikuje od dokaza - njihova vjera je više osobna i živa od one koju puka evidencija može stvoriti«. Drugim riječima, »puka evidencija vodi k pasivnom mišljenju i znanju; no pretpostavke, 'prethodne vjerojatnosti' su kreacija samoga uma i vjera koja postoji u njima je djelatna, bez obzira je li riječ o bogatima ili siromašnima, učenima i nepoučenima, starima i mladima «. Dakle, »vjera se koristi pretpostavljajućim razumijevanjem ili razumom koji počiva na 'prethodnim vjerojatnostima'. To je činjenica, bez obzira što iz toga proizlazi«. Isto, br. 12 . ${ }^{20}$ Isto, X., br. 30.
} 
cijom ili pak formalnim zaključivanjem. Prethodne vjerojatnosti, vjerojatni razlozi uzeti zajedno daju potrebnu sigurnost. Stoga Newman smatra da je vjera, zapravo, pojedinačna instancija mnogih savršeno razumnih uvjerenja koja dosežemo na različite načine. Prema tomu taj način razumijevanja ne počiva strogo na specifičnim argumentima ili dokazima, nego često u igru ulaze i pretpostavke (Pieper!) te očekivanja koja imamo od ranije. ${ }^{21}$

Drugim riječima, možemo vidjeti da je vjera analogna određenom obliku razuma. Razum se može definirati kao sposobnost uma gdje se znanje izvanjskih stvari, bića, činjenica i događaja doseže onkraj osjetila. To je sposobnost kojom se dolazi od percipiranoga do onoga što nije moguće percipirati. Taj oblik razuma kompatibilan je s vjerom. Vjera je stoga forma razuma koja se razlikuje od formalnih, logičkih procesa razuma koji demonstrira konkluzije na osnovu dokaza, tj., kako uviđaju i Newman i Pieper, ona se zasniva više na pretpostavkama, a manje na dokazima. ${ }^{22}$

${ }^{21}$ Netko može legitimno razumijevati stvari na taj neformalan način bez da je u mogućnosti osigurati bilo kakve dokaze ili donijeti nekakve razloge zašto vjeruje u nešto. Tako da ljudi nekada nisu u stanju izreći ono što razumijevaju ili su možda slabi u izricanju onoga što razumijevaju. U tome smislu Newman smatra da filozof i radnik u tvornici koji dijele vjersko uvjerenje dijele iste prethodne vjerojatnosti. Takva vjerovanja na neki način prevladavaju u svima nama bilo da su razumna ili ne. Međutim postoje i određeni ekscesi kada je vjera u pitanju. Naime $\gg$ kada vjerojatnosti koje pretpostavljamo zapravo ne postoje ili su naše želje neumjerene, ili naša mišljenja pogrješna, vjera se degenerira u slabost, ekstravaganciju, praznovjerje, pretjerani entuzijazam, netrpeljivost, predrasude «. Isto, br. 31. Takvih degeneracija vjere svjedoci smo i danas. Dakle, dok razum zahtijeva stroge dokaze, vjera se zadovoljava nejasnim i neispravnim i tu su moguće određene stranputice i ekscesi. Međutim treba biti svjestan i implikacija toga koje navodi Newman pozivajući se na sv. Pavla. Naime sv. Pavao vjeru definira kao »oslanjanje na riječ drugoga « ili »prihvaćanje božanske poruke « ili »podčinjenost intelekta misterijima «. »Vjera «, kaže on, »je već neko imanje onoga čemu se nadamo, uvjerenost u zbiljnosti kojih ne vidimo.« (Heb 11, 1) To je svojevrsna procjena kojoj se nadamo ili za koju želimo da se dogodi; nikako ne zbiljnost koja je dokazana. Njezina čežnja jest glavni dokaz ili, kako ističe Apostol, ona stvara vlastite dokaze tako što je dokaz »zbiljnosti kojih ne vidimo «. I to je uzrok zašto se vjera svijetu čini tako iracionalnom, kako kaže sv. Pavao u poslanicama. Ne da nema utemeljenja u razumu, tj. u dokazu; već zato što se zadovoljava s toliko malo toga tako da svijetu njezin dokaz gotovo da ništa ne znači. Dakle, vidimo, to su te sitnice o kojima govori Newman koje daju praktičku sigurnost. Zbog svega navedenoga vjera je osobito važna jer se ona odnosi na prihvaćanje stvari kao onih koje su realne, prihvaćanje svjedočanstava. Čin vjere cjelovit je u sebi, neovisan o onome što se popularno naziva razumom, odnosno onoga što se obično naziva eksplicitnim razumom (ako tako ne bi bilo, kako bi onda djeca ili neuki ljudi mogli vjerovati u Boga). Isto, br. 34.

${ }^{22} \mathrm{Tu}$ Newman govori o neformalnom načinu razumijevanja koji djeluje ne samo unutar vjere nego i u kontekstu drugih područja ljudskoga djelovanja. Taj oblik razuma zapravo je prisutan u odlukama o različitim političkim pitanjima, ekonomskoj politici, izboru stranačke opcije, književnih ukusa, stavova o vremenu i sl. Sve to, uključujući vjeru, zapravo su oblici razuma koji počivaju na latentnim ili prethodnim vjerojatnostima koje se uzimaju kao sigurne. 
U tom kontekstu Newman razlikuje i teoretsku (matematičku) te praktičku (moralnu) sigurnost. ${ }^{23}$ Teoretska sigurnost proizlazi iz demonstracije, točno određenih pravila logike, tj. tzv. formalnoga (pojmovnoga, eksplicitnoga) zaključivanja koje izgrađujemo obrazovanjem, dok je praktička sigurnost posljedica neformalnoga (realnoga, implicitnoga) zaključivanja, ona je plod savjesti i volje te se zasniva na akumulaciji prethodnih vjerojatnosti i/ili moralnih predispozicija, gdje se također zaključak izvodi iz premisa, ali ne po strogo definiranim pravilima logike i tu nismo svjesni svakoga koraka i svakoga argumenta koji nas dovodi do cilja. ${ }^{24}$

\subsection{Praktična I teoretska Sigurnost}

Praktična sigurnost nastaje konvergencijom razloga i na njoj počiva čitavo naše djelovanje i teorije na koje se u životu oslanjamo. Sigurnost se ne može steći, kako to racionalisti misle, kroz neosobnu prisilu uma i kroz silu formalnih elemenata. To znači da se u konkretnom razumijevanju sigurnost bazira na aktivnom odgovoru uma na težinu argumenta, na životnom prepoznavanju značenja i istine. Nadalje to sigurnosno razumijevanje istine neke tvrdnje jest neotuđivo pojedinačan čin koji se zasniva na mnogo vjerojatnih razloga koji su dovoljno jaki tako da nam mogu dati praktičnu sigurnost koja isključuje protivnost, premda je ona teoretski moguća.

U biti ta praktična sigurnost do koje dolazimo na temelju zaključivanja s pomoću konvergencije mnogih razloga ne može zamijeniti teoretsku, odnosno matematičku sigurnost, tj. ne bismo mogli očekivati da nas neka protivna tvrdnja ne će nikada iznenaditi. Upravo to je onaj »nemir mišljenja « na koji upozorava Pieper, a vidimo da mu Newman daje mnogo šire obrazloženje. ${ }^{25}$

No, dakako, kao što smo u jednom drugom kontekstu ukazali ${ }^{26}$, Newman osobito inzistira na razlikovanju zaključivanja i pristanka jer postoje istine vezane za konkretno na koje ljudi pristaju bezuvjetno, iako ih ne možemo dokazati. Za Newmana je sigurnost pristanak, a karakteristike pristanka jesu bezuvjetnost i cjelovitost i to je ono ključno po čemu se pristanak razlikuje od zaključivanja. Ovdje se postavlja

\footnotetext{
${ }^{23}$ Usp. M. POLJAK, Filozofija spoznaje i logika pristanka Johna Henryja Newmana, Split, 2015., 122.

${ }^{24}$ Slično promišljanje nalazimo i kod Josefa Piepera. Usp. J. PIEPER, O vjeri, 39.

${ }^{25} \mathrm{~K}$. Popper smatra da u opsegu našega spoznavanja ne postoji apsolutna sigurnost te da je naša objektivna znanstvena spoznaja konjekturalna ako se do nje dolazi zaključivanjem koje nastaje kombinacijom mnogih fenomena koji upućuju na jednu stvar, kao i kod konvergencije. Ponekad u životu i ne ćemo tražiti neku čvrstu sigurnost, već će nam biti dovoljno da se zadovoljimo vjerom u to da se ne varamo. Usp. I. MACAN, Filozofija spoznaje, Zagreb, 1997., 111.

${ }^{26}$ Usp. Š. ŠOKČEVIĆ, Milosrđe kao temeljeno uporište personalizma pape Franje i Johna Henryja Newmana, u: I. RAGUŽ, Š. ŠOKČEVIĆ (ur.), O Božjem milosrđu, Đakovo, 135-146., ovdje 139.
} 
pitanje: Smijemo li sigurnim i bezuvjetnim pristankom pristati na nešto što nismo demonstrirali? Ili ta tvrdnja na koju pristajemo mora biti nužno demonstrirana?

Bezuvjetnost se odnosi na neovisnost o premisama što znači da na neku tvrdnju možemo pristati bez da poznajemo premise koje joj prethode, već da pristajemo na temelju konvergencije vjerojatnosti, tj. prethodnih vjerojatnosti. Ili kako kaže Newman: »Um razmišlja i upravlja vlastitim razmišljanjem, a ne tehnički aparat riječi i propozicija. $\ll{ }^{27}$ Osim toga cjelovitost proizlazi iz bezuvjetnosti i odnosi se na to da u pristanku nema stupnjevanja. Upravo je to i glavni jamac sigurnosti.

Za razliku od zaključivanja, koje je uvjetno prihvaćanje tvrdnji, pristanak kao bezuvjetno prihvaćanje tvrdnji sprječava skepticizam. Pristanak je osobni čin, zato što uz razumsko shvaćanje uključuje i moralne predispozicije koje osoba ima. To znači da uzima cjelovitu osobu u obzir. To nam objašnjava zašto se Newman za sigurnost koja proizlazi iz neformalnoga zaključivanja koristi izrazom moralna. Naime riječ je o tome da je on htio istaknuti da pristanak u tom slučaju ovisi o moralnim predispozicijama, ali i o $\gg$ smislu za izvod $\ll(\gg$ illative sense $\ll){ }^{28}$

Prema tomu za Newmana, kao i za Piepera, sigurnost je vezana za vjeru, zato Pieper govori o vjeri kao znanju, ali svakako da i prema jednom i prema drugom postoji mogućnost pogrješne sigurnosti, što onda potencira latentni »nemir mišljenja «, ali to nije sumnja, naglasit će i Pieper i Newman..$^{29} \mathrm{U}$ načelu važno je istaknuti da uz neformalno zaključivanje ključnu ulogu u kontekstu kršćanske vjere imaju moralne predispozicije. Kad je riječ o moralnim predispozicijama, onda tu Newman ubraja: stanje srca, moralno stanje, moralni osjećaj ili biblijske izraze poput »nježno, otvoreno srce $\ll .{ }^{30}$ Stoga ćemo u sljedećem dijelu rada pojasniti ulogu i značaj moralnih predispozicija za vjeru.

${ }^{27}$ J. H. NEWMAN, An Essay in Aid of a Grammar of Assent, Middletown, 2015., 109.

${ }^{28}$ Usp. isto, 163-182. Na drugome mjestu za »illative sense « koristimo se prijevodom »osjećaj za zaključivanje «. Ovisno o kontekstu mislimo da su oba prijevoda dovoljno dobra. Usp. Š. ŠOKČEVIĆ, »Milosrđe kao temeljeno uporište personalizma pape Franje i Johna Henryja Newmana «, 141. Vrlo dobra analiza toga pojma usp. M. POLJAK, Filozofija spoznaje i logika pristanka Johna Henryja Newmana, 136-150.

${ }^{29}$ Pristanak vjere nekompatibilan je sa sumnjom. Tako u raspravi Faith and Doubt vidljivo je da Newman zapravo razumijeva sumnju kao suspenziju pristanka. Središte njegova odbijanja sumnje nalazi se u tome da ju on vidi kao oblik nevjerovanja. $\gg$ Ako bi se vjerniku dopustilo da sumnja, to bi bilo kao da bismo dopustili vjerniku da ne vjeruje u ono što smatra da je vječna istina $\ll$, smatra Newman. Sumnjati u istine vjere $\gg$ ne znači vjerovati i stoga kada je netko u stanju sumnje, on nema vjere $\ll$. U tom smislu, prema Newmanu, sumnja je zapravo »ekvivalentna gubitku vjere «. J. H. NEWMAN, Discourses Addressed to Mixed Congregations, London, 1906., 215., 220., 227.

${ }^{30}$ Tako, kad je riječ o prihvaćanju kršćanstva, Newman smatra da su poslušnost savjesti, ispravno razlikovanje dobra i zla, istinoljubivost, revnost u traženju istine te posebno ljubav i želja za Bogom 


\section{Moralne predispozicije za vjeru}

Nepobitnih argumenata za vjerodostojnost nekoga čovjeka može biti dovoljno, ali nijedan nas argument ne može prisiliti da mu vjerujemo. Vjera je potpuno slobodan čin na koji nas ne može prisiliti »ni neproturječnost onoga što je pred očima « ni težina argumenata (jer moguće je da ponekad imamo i čvrste argumente da u nešto povjerujemo, ali mi u to svejedno ne povjerujemo, ne damo pristanak u vjeri). ${ }^{31}$ Prema tomu vidimo da vjera ovisi o moralnim krjepostima, karakteru, temeljnim stavovima, svjetonazorima, načelima djelovanja i spoznaje. Drugim riječima, vjera ovisi o određenim moralnim predispozicijama, koje stječemo preko odgoja i obrazovanja, utjecaja okoline, interakcije s drugim ljudima, raznih iskustava kojima smo izloženi.

Te moralne predispozicije toliko su snažne da zahvaljujući njima možemo prihvatiti neku tvrdnju za koju nemamo dovoljno dokaza. Jednako tako moralne predispozicije kompenziraju formalne nedostatke dokaza. Tako su ljubav prema istini i težnja za njezinim posjedovanjem samo neke od moralnih predispozicija koje su nam potrebne da pri susretu s istinom mi ju i prihvatimo. To bi značilo da ako osoba ne želi spoznati istinu, ako joj nije otvorena te nema ljubav prema njoj, onda ju unatoč svim intelektualnim sposobnostima ne će ni dosegnuti. Moralne predispozicije pomažu nam i u situacijama kada trebamo prihvatiti neke tvrdnje koje smo samo shvatili, ali nismo do kraja razumjeli. One su nešto što utječe mnogo dublje na razinu našega spoznajnoga života te ga može pozitivno ili negativno oblikovati.

Kada je riječ o moralnim predispozicijama za vjeru za Piepera i Newmana osobito je važna slobodna volja, koja se mora svesti i na um te na samostalno gledanje i ona se također (što je vrlo važno) usmjerava prema osobi. Mi možemo smatrati nečije iskaze ispravnim, pametnim, domišljatim, ali da bismo vjerovali, tj. da bismo te iskaze prihvatili na način vjere, potrebna nam je volja. Ja vjerujem, ne zato što »vidim, uviđam ili zaključujem nešto istinito, nego zato što hoću nešto dobro $\ll^{32}$, kaže Pieper.

\subsection{VAŽNOST VOLJE}

Prema Newmanu čin vjere jest slobodan čin i osoba preuzima odgovornost za njega. Iz toga slijedi da čin vjere također uključuje djelovanje volje. Newman smatra da

ključne moralne predispozicije. Newman kaže da je ljubav jedan od glavnih uzroka pristanka na nadnaravne istine Objave te ističe da je ljubav roditelj vjere i da mi vjerujemo Božjoj riječi zato što ju ljubimo. Usp. M. POLJAK, Filozofija spoznaje i logika pristanka Johna Henryja Newmana, 187.

${ }^{31} \mathrm{~J}$. PIEPER, O vjeri, 25.

${ }^{32}$ Isto, 27. 
vjera nije proizvoljan izbor koji proizlazi iz neovisnoga čina volje, odvojenoga od razuma. U činu vjere ne događa se situacija da se vjernik u susretu s Božjom Objavom nađe pred zidom i da je prisiljen prihvatiti ili odbaciti tu objavljenu istinu kroz čin volje. Nije takva situacija da neformalno zaključivanje ide do jedne točke kada uskače volja i onda se događa čin vjere. Takva interpretacija bila bi čisti voluntarizam i on je u tom kontekstu nešto neprihvatljivo za Newmana.

Ferreira, analizirajući pojam volje kod Newmana, pravi distinkciju između dviju uloga volje, gdje se stvara okvir za razumijevanje toga kako volja djeluje u činu katoličke vjere. Čin volje u dostizanju sigurnosti religiozne vjere različit je od djelovanja volje $\mathrm{u}$ afirmaciji vjere. $\mathrm{U}$ procesu dostizanja sigurnosti vjere volja djeluje kroz dinamiku onoga što Ferreira naziva $\gg$ aktivno prepoznavanje $\ll .{ }^{33}$ Naime volja $\mathrm{u}$ činu religiozne (katoličke) vjere naginje osobnoj racionalnoj evaluaciji, ali ona nije prisiljena njome. Stoga čin katoličke vjere koji naginje, ali nije ograničen, aktivno prepoznaje istinu stvarnosti i tvrdnji kršćanske Objave i pokreće osobu prema pristanku. Volja ne prisiljava pristanak, no pristanak ne možemo dati bez volje ili protiv volje. Prema tomu vidimo da je volja uključena u cjelokupan osobni proces dostizanja sigurnoga pristanka na vjeru. U svakom slučaju, i prema Newmanu i prema Pieperu, vjerujemo zato što hoćemo nešto dobro, a to dobro zapravo je »zajedništvo s onim koji zna « i kojega uočavamo, da se poslužimo Ferreirinim izrazom, aktivnim prepoznavanjem. U tom smislu ljubav je pračin volje i ona je za Newmana i Piepera važna moralna predispozicija za vjeru.

\subsection{VAŽNOST LJUBAVI}

Ljubav je $\gg$ temeljni oblik svakog htijenja i trajno ishodište svakoga voljnoga poticaja $\ll^{34}$, reći će Pieper. Dakle ono što je normativno u kontekstu vjere nije toliko istina objektivnoga sadržaja, nego je to uvid da je dobro na iskaz nekoga drugoga objektivni sadržaj držati istinitim i stvarnim, ali na to dobro ne odgovara spoznavanje, nego htijenje. ${ }^{35}$ I prema Newmanu vidjeli smo da je za vjeru važna slobodna volja, htijenje. Ona se mora svesti i na um te na samostalno gledanje, da ne bi bila proglašena zanesenjaštvom, te nas usmjerava prema osobi. Za njega vjera nije konkluzija iz premisa i ono što je potrebno za vjeru nije argument, nego baš čin volje. No, ako je vjera način razumijevanja koji počiva na pretpostavkama (Pieper) ili prethodnim vjerojatnostima (Newman), postavlja se pitanje ima li kakvoga kriterija po kojem se mogu definirati istine kršćanstva. Što sprječava da to razumijevanje

\footnotetext{
${ }^{33}$ M. J. FERREIRA, Doubt and Religious Commitment: The Role of the Will in Newman's Thought, Oxford, 1980., 75.

${ }^{34}$ J. PIEPER, O vjeri, 29.

${ }^{35}$ Isto, 27.
} 
ne sklizne u dogmatizam ili praznovjerje? Ili drugim riječima, što ako su moralne predispozicije različite i kao takve vode do suprotstavljenih stavova? Prethodne vjerojatnosti nedvojbeno mogu poduprijeti i prave i lažne tvrdnje, također moralne predispozicije nisu po sebi jasan kriterij određivanja istine i laži. ${ }^{36}$

Dakle vjeri je nužan nekakav korektivni princip koji bi ju trebao osigurati od toga da se ne zapusti i postane fanatizam ili fundamentalizam (koji rađa terorizam). Tako se najčešće u tom kontekstu spominje razum jer se ističe da je vjera građena na razumu i razum je njezin zaštitnik. Tako se smatra da $\gg$ njegujući razum čovjek na istom stupnju dolazi do spoznaje i do trezvenoga odnosa prema Evanđelju $\ll .{ }^{37}$ Smatra se da će njegova religija biti racionalna koliko je sam upoznat s time zašto i u što vjeruje. Zato se drži da je važno ljudima omogućiti obrazovanje kako bi otvorili vlastite umove, prosvijetlili ih, omogućili im da reflektiraju, uspoređuju, istražuju, zaključuju itd. Na taj način smatra se da se smanjuje vjerojatnost da će ti ljudi odlutati od vjere, a ujedno će se spriječiti praznovjerje.

Stoga je razum važan za vjeru, međutim Newman smatra da je istinska zaštita vjere zapravo sadržana $\mathrm{u} \gg$ ispravnom stanju srca $\ll{ }^{38}$ Drugim riječima, ljubav je ta koja daje život vjeri, koja ju disciplinira, koja ju štiti od netrpeljivosti, lakovjernosti, fanatizma i fundamentalizma. Kako lijepo primjećuje Newman, ljubav je ta koja vjeri daje oči, ruke i noge. To je ljubav koju još skolastika prepoznaje u terminu $\gg$ fides formata caritate $\ll .{ }^{39}$ Zato će Pieper, citirajući Newmana, reći da mi $\gg$ vjerujemo zato što ljubimo $\ll .{ }^{40}$ Newman ističe da je ispravno stanje srca ono koje štiti vjeru, drugim riječima, odbacivanje vjere proizlazi iz pogrješke srca, a ne uma. Kada se

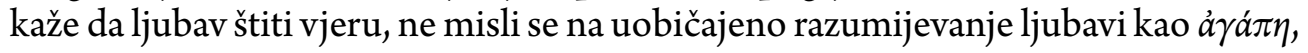
nego se misli na unutarnje sklonosti ili, još preciznije, na sazrijevanje intelektualnih, teoloških i moralnih vrlina. Ta ljubav o kojoj govori Newman zapravo je pia affectio ili pak voluntas credendi koja usmjerava intelekt prema vjeri. Dakle takav um, obogaćen takvim predispozicijama, stvara i na neki način čuva i disciplinira vjeru od svih mogućih nedostataka. To je zapravo fides formata caritate ili ljubav koja

\footnotetext{
${ }^{36}$ Problem s prethodnim vjerojatnostima vidimo da se često krije u tome što se njima mnogi mogu koristiti kao izgovorom $\gg$ za sve vrste predrasuda i netrpeljivosti i mogu voditi k lakovjernosti i praznovjerju; a $s$ druge strane u slučaju nevjere one nude ispriku za nerazumljivu bezdušnost «. Prema tomu prethodne vjerojatnosti mogu biti jednako dostupne za ono što je istina, ali i za laž. Riječ je o tome da one ne donose inteligibilno pravilo što treba vjerovati, a što ne. Drugim riječima, tim argumentom prethodnih vjerojatnosti može se koristiti kao argumentom za kršćanstvo, ali jednako tako može se upotrebljavati i kao argument protiv kršćanstva. OUS, XII., br. 13.

${ }^{37}$ Isto, br. 14 .

${ }^{38}$ Isto, br. 16.

${ }^{39}$ Isto.

${ }^{40}$ Isto, br. 21., 25.
} 
oblikuje vjeru. Kao intelektualni čin vjera počiva na pretpostavkama i bez odgovarajućega vodstva ona može skrenuti u smjeru moralnih, teoloških ili pak duhovnih stranputica. Može se naime dogoditi da vjera uništi razum, no ljubav to sprječava. ${ }^{41}$

To Newmanovo inzistiranje na moralnim predispozicijama treba shvaćati mnogo šire. On odbacuje strogi racionalizam, ali se jednako tako suprotstavlja svođenju kršćanstva na religiju osjećaja. Iako vjera ima intelektualnu dimenziju, nju se ne može svesti na nekakav objektivni proces razumijevanja jer prethodne vjerojatnost $\mathrm{i}$ mogućnosti bitno utječu na formiranje uvjerenja. Međutim treba imati na umu da pia affectio ne zapovijeda intelektu da pristane bez dovoljnoga ratio volendi. To je etička i epistemološka odgovornost da se potvrdi ono što razum prezentira kao dovoljno za pristanak. U tom kontekstu Newmanova filozofija vjere može se promatrati i kao pokušaj da se stvori ravnoteža između subjektivne i objektivne dimenzije religiozne vjere. Stoga nas njegova promišljanja o sigurnosti vjere transponiraju na područje religiozne (katoličke) vjere. ${ }^{42}$

\section{Sigurnost religiozne (katoličke) vjere}

U Svetome pismu vidljivo je da je religiozna vjera »novi princip djelovanja, najmoćniji u utjecaju na srce i na božansko viđenje nas samih i također ona ima tu

${ }^{41}$ Prema tomu vidimo da ljubav zapravo usmjerava vjeru, ona je njezin princip po kojem djeluje i jedino takva vjera ima svoju snagu. Dakle takva ljubav ne isključuje á $\gamma a ́ \pi \eta$, već ona zapravo ide pu-

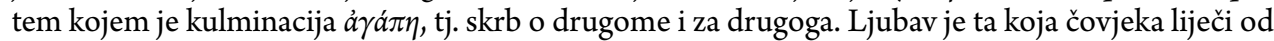
predrasuda i onda njegovoj vjeri daje čvrst oslonac koji ju čini stabilnom i, u konačnici, razumski opravdanom. Ohol čovjek, ne ljubi istinski drugoga, on je zatvoren u svoj sebični ego tako da je često sklon predrasudama i njegova je vjera manjkava. On odbija bilo kakav oblik ovisnosti o bilo kome, osim da ovisi sam o sebi.

${ }^{42}$ Subjektivna dimenzija uključuje moralnu odgovornost da se slijede uvidi razuma, dok objektivna dimenzija upotrebljava razum da bi tumačila određene podatke. $U$ obama slučajevima Newman izbjegava relativizam (jer ne prepušta sve volji), a s druge strane izbjegava i antiintelektualizam (braneći ulogu razuma). Kao i kod Piepera tako i kod Newmana postavlja se pitanje motiva kredibilnosti kršćanske vjere. Za Newmana kod kršćanske (katoličke) vjere motivi mogu biti objektivni i subjektivni. Objektivni su zajednički jer ih svaka inteligentna i iskrena osoba može prihvaćati kao valjane. No njihov je nedostatak u tome što nisu svima dostupni. Mali broj ljudi imao je priliku imati uvid u dokaze za Božju opstojnost ili pak vidjeti čuda, što bi spadalo u tu kategoriju objektivnih motiva. Subjektivni motivi vezani su za pojedinca, osobu i kao takvi proizlaze iz već spomenutoga neformalnoga zaključivanja koji upućuju na zaključak, no ne vode nužno do njega i time ga ne prisiljavaju. Prednost tih subjektivnih kriterija jest u tome što su svima dostupni. No, prema Newmanu, kao uostalom i prema Pieperu, u kontekstu kršćanske vjere mnogo toga ostaje misterij, a to je zato što Objava i kršćanska vjera za objekt imaju Boga koji nadilazi ljudsku stvarnost, a drugi je razlog što se objava izriče ograničenim ljudskim jezikom. Sigurnost kršćanske (katoličke), kao i vjere u općespoznajnome smislu, Newman veže uz pristanak i to realni pristanak, koji predstavlja osobni odnos s Bogom. 
moć da može pobuditi prijezir ili učiniti smiješnim ovaj svijet $\ll .^{43}$ Dakle vjera je za Newmana oruđe znanja i djelovanja, nepoznata svijetu, »princip 'sui generis', odvojen od onoga što se uobičajeno podrazumijeva pod razumom $\ll$ ". ${ }^{44}$ Vidjeli smo da je zato po njemu »krivo vjerovanje svoditi na dokazivanje ili na tip zaključivanja nastao na procesu razumijevanja i rješenja zasnovanih na kalkuliranju «. Ako bi vjera bila takav princip, kako bi uopće mogla biti nešto novo i neobično? ${ }^{45}$ Dakle vidljivo je da, prema Newmanu, eksplicitni dokazi ne mogu biti preduvjet kršćanskoga vjerovanja ili procesa oblikovanja uvjerenja. ${ }^{46}$

No unatoč tomu Newman smatra da vjera mora biti povezana s osjetnim uvidom i razumom. ${ }^{47} \mathrm{U}$ pokušaju da istraži razliku između vjere i razuma naš autor primjećuje prvo da je »neporecivo to da razum ima moć analize i kritike u svakom mišljenju i ponašanju i da ništa nije istinito ili ispravno ako se ne može opravdati i ako nije

\footnotetext{
${ }^{43}$ Posebnosti vjere, prema Newmanu, zabilježene su u sljedećim biblijskim citatima: »Isus im odvrati: Imajte vjeru Božju. Zaista, kažem vam, rekne li tko ovoj gori: 'Digni se i baci u more!' i u srcu svome ne posumnja, nego vjeruje da će se dogoditi to što kaže - doista, bit će mu! Stoga vam kažem: Sve što god zamolite i zaištete, vjerujte da ste postigli i bit će vam!« (Mk 11, 22-24). I ponovno: »Nato mu Isus reče: 'Što? Ako možeš? Sve je moguće onomu koji vjeruje!'« (Mk 9, 23). Zatim: »Uistinu, besjeda o križu ludost je onima koji propadaju, a nama spašenicima sila je Božja. Ta pisano je: Upropastit ću mudrost mudrih, i odbacit ću umnost umnih. Gdje je mudrac? Gdje je književnik? Gdje je istraživač ovoga svijeta? Zar ne izludi Bog mudrost svijeta? Doista, kad svijet u mudrosti Božjoj Boga ne upozna mudrošću, svidjelo se Bogu ludošću propovijedanja spasiti vjernike.« (1 Kor 1, 18-21) Ponovno: »Nego što veli? 'Blizu ti je Riječ, u ustima tvojim i u srcu tvome' - to jest Riječ vjere koju propovijedamo... Dakle: vjera po poruci, a poruka riječju Kristovom.« (Rim 10, 8.17). I zatim: »Jer još malo, sasvim malo, i Onaj koji dolazi doći će i neće zakasniti; pravednik će moj od vjere živjeti ... « (Heb 10, 37-38). I onda, odmah nakon toga, riječi teksta: $\gg \mathrm{A}$ vjera je već neko imanje onoga čemu se nadamo, uvjerenost u zbiljnosti kojih ne vidimo.«OUS, $\mathrm{X}$., br. 4.

${ }^{44}$ Isto, br. 5.

${ }^{45}$ Isto.
}

${ }^{46}$ Newman navodi mnogobrojne primjere iz Svetoga pisma gdje jasno vidimo da osobe zahvaljuju Kristu i njegovim učenicima na vjeri, koju svijet ne percipira kao racionalno uvjerenje na temelju dokaza. Primjerice hromi čovjek koji je bio postavljen kod hramskih vrata zvanih Divna i kojega je vlastita vjera izliječila nakon što mu je Petar rekao: »Pogledaj u nas! « I drugi hromi čovjek u Listri nije vidio ni jedno čudo sv. Pavla, već ga je samo čuo kako propovijeda i tada ga Apostol: »pronikne pogledom, vidje da ima vjeru u spasenje pa mu iza glasa reče: 'Uspravi se na noge!' « $(\mathrm{Dj} 14,10)$ $S$ istim ciljem izgovorene su i Gospodinove riječi kada je sveti Ivan Krstitelj poslao svoje učenike da ga upitaju je li on onaj koji ima doći ili drugoga da čekaju. On je činio čudesa da ga uvjeri, no doda: »Blago onom tko se ne sablazni o mene.« (Mt 11,6) I kada je sveti Toma sumnjao u njegovo uskrsnuće, on mu je dao jasan dokaz koji je tražio, no uz to je dodao: »Budući da si me vidio, povjerovao si. Blaženi koji ne vidješe, a vjeruju! « (Iv 20, 29). Drugom je prigodom rekao: »Ako ne vidite znamenja i čudesa, ne vjerujete! «(Iv 4, 48). Isto, br. 10.

${ }^{47}$ Isto, br. 11. 
u određenom smislu, dokazano razumom te sve dok vjerske doktrine mogu biti prihvaćene razumom mogu se smatrati istinitima $\ll{ }^{48}$ Iako razum igra važnu ulogu u oblikovanju uvjerenja, to ne znači da vjera proizlazi iz razumskoga obrazloženja kršćanskoga uvjerenja. ${ }^{49}$ To znači da razum može analizirati temelje vjere, ali nikako nije izvor iz kojega proizlazi vjera. ${ }^{50}$

Stoga je potpuno pogrješno smatrati da su razumski procesi sine qua non istinskoj vjeri. Kada se kaže da evanđelje podrazumijeva racionalnu vjeru, to ne znači ništa više od toga da je vjera u skladu s ispravnim razumom $u$ apstraktnom smislu, a ne da je vjera rezultanta djelovanja razuma. ${ }^{51}$ Da racionalna vjera upravo uključuje prethodne vjerojatnosti, vidimo i u primjeru koji navodi Newman, a odnosi se na sv. Pavla koji propovijeda Atenjanima, gdje im on govori da dolazi kao glasnik Boga kojega oni već štuju, iako toga uopće nisu svjesni. Dakle vidimo kako Pavao zapravo aludira na prethodnu vjerojatnost Objave.

No što je zapravo dokaz koji je on dao da bi prikupio te prethodne vjerojatnosti, na koje se referira, u ime poruke koju je donio? Vrlo mali dokaz; nije riječ o čudu, nego o njegovoj riječi da je Bog uskrisio Krista od mrtvih; vrlo sličan dokaz dan mnogim ljudima danas. U tom slučaju nitko ne će reći da je tu riječ o strogome dokazu, međutim osobno držanje apostola Pavla podržano s mnogim prethodnim vjerojatnostima može biti sasvim dovoljno da čvrsto povjerujemo. Dovoljno, ne doduše u sebi, nego za one koji vole i na taj su način usmjereni tomu da vjeruju. ${ }^{52}$

${ }^{48}$ Isto, br. 13.

${ }^{49} \mathrm{U}$ tom kontekstu Newman pravi jasnu razliku između literarnoga kriticizma i poezije. Naime vrjednovanje poezije i stvaranje nisu isto. Kreativni umjetnik (pjesnik) nije najvjerojatnije u stanju dati točnu analizu onoga što on virtuozno zamjećuje i izražava. Književni kritičar na sličan način, može ocijeniti ono što nije u stanju stvoriti. Sličan primjer toga nalazimo i u kontekstu Newmanova govora o savjesti. Naime »nitko neće kazati da je savjest protivna razumu, ili da njezine zapovijedi ne mogu biti stavljene u polemičku formu; međutim tko može tvrditi da ona nije izvorni princip te da ovisi o nekim prethodnim razumskim procesima? « Jednako je i s vjerom. Usp. isto.

${ }^{50}$ Isto.

${ }^{51}$ Isto, br. 14. Osim toga važno je naglasiti da vjera postoji neovisno o razumu. Hoće li netko reći da dijete ili neobrazovana osoba ne može s pravom djelovati u vjeri, bez da je u mogućnosti da podastre razloge zašto on na taj način djeluje? Koji zadovoljavajući uvid on ima u dokaze kojima se služi kršćanstvo? Koji logički dokaz božanstva? Ako nema ni jedan, vjera koja se promatra kao unutrašnja navika ili djelovanje ne zasniva se na istraživanju i ispitivanju, već ima svoju osnovu, koja god da je, kao što to ima i savjest. Vjera daje stvaralačku notu našem životu, a razum analitičku.

${ }^{52}$ Taj primjer apostola Pavla možda najbolje oslikava Newmanovo razumijevanje vjere i na neki način opravdava njegova stajališta u tom smislu da je »djelo razuma, ali onog kojega bi svijet nazvao slabim, lošim ili nedovoljnim razumom; zato što više počiva na pretpostavkama, nego na dokazu «. Isto, XI., br. 3. 
Prema tomu vidimo da vjera prihvaća Božansku Objavu na dvama temeljima: svjedočanstvo i mogućnost (odnosno vjerojatnost) poruke. To je zapravo ono što Newman naziva neformalnim zaključivanjem. Formalno i neformalno zaključivanje obilježeni su stupnjevitošću u smislu da ovise o jačini premisa koje nas dovode do zaključka. Formalno zaključivanje temelji se na dedukciji i ono nas gotovo potiče na pristanak, dok se premise kod neformalnoga zaključivanja, kao što smo vidjeli, nazivaju prethodne vjerojatnosti jer nas vode prema zaključku i počivaju na indukciji koja je promjenjiva s obzirom na to da nekada daje mnogo prostora da osobno pristanemo na izvode, a ponekad ostavlja vrlo malo prostora. Formalno ili neformalno zaključivanje $^{53}$ ako se uzmu zasebno nisu dostatni, zato je važno uzeti u obzir oba oblika zaključivanja i na temelju njih donositi adekvatne prosudbe. ${ }^{54}$

To je potvrda opravdanosti Newmanova i Pieperova polazišta. Oni pod prizmom analogije promatraju odnos vjere u općespoznajnom smislu i religiozne vjere. Religiozna vjera izazov je za nas jer trebamo prihvatiti objektivni sadržaj koji ne možemo ispitati te imamo posla sa svjedokom kojega ne susrećemo neposredno. Na koji način možemo znati je li objektivni sadržaj, tj. zahtjev Objave uistinu božanskoga podrijetla? Suglasnost u činjeničnost Objave, među ostalim, počiva na meditaciji o čovjekovoj metafizičkoj situaciji. Ako ta metafizička bit, koja je na neki način smisao ljudskoga života, uključuje to da čovjek po naravi participira i u nadljudskoj zbiljnosti i da u tom kontekstu Božji govor priznaje kao nešto moguće ili kao nešto što se može očekivati, upravo je time već rekao da vlastito prirodno znanje nije dovoljno. ${ }^{55}$

Također kao drugi uvjet važna je nepristranost, otvorenost, pozornost koja seže do dna duše, kako kaže Pieper. Otvorenost za moguću Objavu nije nešto nadnaravno, nego pripada naravi ljudskoga duha i to zbog istoga onoga razloga zbog kojega je duša sposobna primiti nadnaravni, novi život milosti. ${ }^{56}$ Otvorenost za to je nešto što po naravi pripada ljudskom duhu, inače se ne bi uopće moglo očekivati

\footnotetext{
${ }^{53}$ Newman spominje i još jedan oblik zaključivanja - tzv. naravno zaključivanje koje naziva i materijalno zaključivanje, a to je zapravo najprirodniji način razumijevanja od stvari do stvari, od konkretnoga prema konkretnome, od cjeline prema cjelini. To nije zaključivanje od propozicije prema propoziciji. Ne postoji svjestan proces u kontekstu naravnoga zaključivanja. Newman taj proces naziva i spontanim razumijevanjem. J. H. NEWMAN, An Essay in Aid of a Grammar of Assent, 156.

${ }^{54}$ Iz tih promišljanja možemo zaključiti da je vjera, prema Newmanu, spontani način razumijevanja stvarnosti. Obrazloženje utemeljeno na izvanjskim argumentima odgovarajuće je, no nije nužno za oblikovanje vjerovanja. Vjera počiva na vjerojatnom, hipotetskom stupnju zaključivanja zasnivajući se na procesima stvaranja uvjerenja. U kontekstu vjere ključno je zapravo holističko promišljanje koje uključuje integraciju subjektivne i objektivne dimenzije kršćanskoga vjerovanja.

${ }^{55} \mathrm{~J}$. PIEPER, O vjeri, 56.

${ }^{56}$ Isto, 57.
} 
od čovjeka. Treći uvjet, koji je i odlučujući, jest da vjernik prvotno ima posla s Nekim, s Osobom (pisano velikim slovom). Bez njegova svjedočanstva uopće se ne bi vjerovalo u objektivni sadržaj. Dakle onaj komu se vjeruje zapravo je ključan. $\mathrm{U}$ tome leži i glavna razlika između religiozne vjere i svake druge vjere. Naime u religioznom smislu onaj komu se vjeruje jest Utjelovljeni Bog. ${ }^{57}$ Zato u kontekstu Objave, u kontekstu Božjega utjelovljenja, od vjernika se očekuje taj radikalni skok, tako da tu postoje nedogledne mogućnosti uvjerenosti koje je vrlo teško razumski, argumentirano dokazati. No, opet prema Pieperu, otvoriti se cjelini stvarnosti i na temelju manje savršenih uvjerenja vjerovati bolje je nego isključivo čekati egzaktne provjerene dokaze.

Newman smatra da se onoga komu je stalo da ništa ne propusti iz cjeline životno važne istine ne može prekoriti da je nekritičkoga duha ako više voli ne čekati na najsavršeniji mogući dokaz. Newman uvijek iznova govori: ljudi su odviše skloni pričekati u miru dok im kući ne stignu dokazi za činjeničnost objave, kao da su u položaju sudaca, a ne u položaju onih kojima je ona potrebna. Oni su odlučili ispitati Svemogućega bez strasti i sudački, posve nepristrano, trijezne glave. ${ }^{58}$

Prema Newmanu sličnost religiozne (katoličke) vjere i vjere u općespoznajnom smislu vidi se u trima točkama: i jedna i druga uključuju posredništvo i svjedočanstvo; obje su osobne i interpersonalne; kod jedne i kod druge pristajemo na istinitost tvrdnji koje ne možemo dokazati. Razlike su također tri: kod religiozne (katoličke) vjere pristajemo na tvrdnje koje nadilaze naš razum, katolička vjera zasniva se na milosti, dok se vjera u općespoznajnom smislu odnosi na ljudske, naravne moći i treća razlika jest razlika u svjedocima. Svjedok i onaj komu vjerujemo u općespoznajnom smislu jest čovjek, dok je kod katoličke vjere to Bog (vidimo slično kao i Pieper). Oni su ujedno i izvori sigurnosti. ${ }^{59}$

Također proces dolaženja do vjere možemo reći da je analogan umnom dolaženju do sigurnosti kada su u pitanju konkretne ljudske istine. Čin katoličke vjere zapravo uključuje iste one elemente koje sadrži ljudska sigurnost i vjera u općespoznajnom smislu kada je riječ o konkretnim istinitim tvrdnjama uz, dakako, Božju riječ i Božju milost. Prema Newmanu prethodne vjerojatnosti pomažu pojasniti ulogu milosti. Milost je, zapravo, božansko nadahnuće Duhom Svetim koje pomaže osobi u činu vjere. Bog se objavljuje i utječe na to da vjernik prihvati Objavu. Milost je prema tomu nadnaravni element kada je vjera u pitanju. Ona nadahnjuje vjernika da razvija osjećaje koji omogućavaju osobi da prihvati dokaze koji su mogući ili vjerojatni

\footnotetext{
${ }^{57}$ Isto, 50.

${ }^{58}$ Isto, 60.

${ }^{59}$ Usp. M. POLJAK, Filozofija spoznaje i logika pristanka Johna Henryja Newmana, 168-172.
} 
(slabi). Ti osjećaji jesu ljubav velikoga Objekta vjere, spremnost da mu vjerujemo, strah da propustimo ili izgubimo ono što dolazi od njega. Kada bi vjera počivala samo na razumskim osnovama, ne bi bilo potrebe za nadnaravnim, za milošću. Newman govori o vjeri kao formi, činu razuma. Kao čin razuma vjera je cjelovita u sebi, autonomna. Ona ne ovisi o prijašnjem činu razuma. ${ }^{60}$

\section{Zaključak}

Uz brojne sličnosti u filozofskom pristupu vjeri Piepera i Newmana karakteriziraju i neke razlike. Tako možemo primijetiti da se Newman ne zadržava samo na filozofskom pristupu, tj. ne pristupa zadanoj problematici samo kao filozof (za razliku od Piepera) već i kao teolog. On, reflektirajući o vjeri, promišlja i o brojnim teološkim dimenzijama vjere i vjerske spoznaje kao što su odnos čina i objekta vjere, pitanje Božje milosti, Božje riječi, odnosa ljudske i božanske vjere. Tim temama, dakako, nismo mogli ovdje opširnije pristupiti.

Također razlika između te dvojice autora vidljiva je i u pristupu problematici sigurnosti vjere gdje vidimo da Newman mnogo studioznije i opširnije pristupa tomu pitanju. To ne znači da Pieper zanemaruje tu temu. Naprotiv, on implicitno koafirmira glavne Newmanove izvode kada je riječ o tom području. No takav pristup često onda i zahtijeva dodatno tumačenje, te smo morali poduzeti detaljno istraživanje brojnih Newmanovih govora i propovijedi. Uzevši u obzir tu činjenicu, a da bismo ostvarili ciljeve koje smo si zadali na početku, nismo se mogli osloniti ni na neke već utabane staze, tj. slične usporedbe te dvojice autora jer ih u sustavnijem obliku u referentnoj literaturi i nema. No to nam je samo bio dodatni izazov i poticaj da analiziramo doprinos te dvojice autora navedenoj problematici te smo uočili da, iako ju prati konstantni nemir mišljenja, vjerska spoznaja može biti itekako sigurna ako se zasniva na prethodnim vjerojatnostima, neformalnom zaključivanju i pristanku koje međusobno povezuje smisao za izvod kao moć prosuđivanja i zaključivanja u svojoj savršenosti. ${ }^{61}$

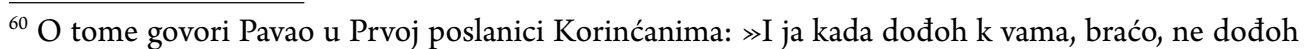
$s$ uzvišenom besjedom ili mudrošću navješćivati vam svjedočanstvo Božje jer ne htjedoh među vama znati što drugo osim Isusa Krista, i to raspetoga. (... ) I besjeda moja i propovijedanje moje ne bijaše u uvjerljivim riječima mudrosti, nego u pokazivanju Duha i snage, s unutrašnjim i duhovnim uvjerenjem, da se vjera vaša ne temelji na mudrosti ljudskoj, naravnom razumu, nego na snazi Božjoj. (...) Naravan čovjek ne prima što je od Duha Božjega; njemu je to ludost i ne može spoznati jer po Duhu valja prosuđivati. Duhovan pak prosuđuje sve, a njega nitko ne prosuđuje. Jer tko spozna misao Gospodnju, tko da ga pouči? « (1 Kor 2, 1-2.4.14-16a)

${ }^{61}$ To je intelektualna krjepost zahvaljujući kojoj možemo uočiti međusobno slaganje mnoštva različitih argumenata i donijeti sud je li razumno pristati na određenu propoziciju ili nije. Preko njega imamo sposobnost da različite argumente povežemo u jednu koherentnu cjelinu.
} 
Za Newmana i Piepera sigurnost vjere počiva na činjenici da je vjera intelektualni čin koji ima određene moralne predispozicije. Ispravna vjera jest $\gg$ razumijevanje na svetim, pobožnim i prosvjetljujućim pretpostavkama $\ll$, reći će Newman. ${ }^{6} \mathrm{Mi}$ svaki dan djelujemo, ali bez savršene sigurnosti i prihvaćamo većinu, ako ne i sve objektivne spoznaje, premda su samo konjekturalne, tj. vjerojatne ili predvidive, praktički sigurne. Dakle ovdje govorimo o pojmu vjerojatnosti koja zapravo nije u suprotnosti s demonstrativnim ili sigurnim kao takvim, već s apstraktnim formama sigurnosti i formalnim tipom zaključivanja. Ono što je zapravo ključno jest to da vjerojatnost ima elemente po kojima može pružiti sigurnost i jasnu demonstraciju. ${ }^{63}$

Za Newmana »vjeru krasi odvažnost, no ona se izlaže opasnosti promišljeno, ozbiljno, trezveno, pobožno, ponizno uzevši u obzir posljedice, no ne izbjegavajući žrtvu. Takva vjera nema tendencije prema praznovjerju «. Dakle prava, istinska vjera prema Newmanu jest »pokušaj da se ide prema naprijed, u sumrak, no ne bez traga i smjera. Vjera je kretanje od nečega poznatog u nepoznato, no i dalje na uskom putu istine uzimajući u obzir i dužnost koja ju prati, nebesko svjetlo koje ju vodi i animira $\ll \cdot{ }^{64}$ Drugim riječima, prati ju nemir mišljenja, kako bi rekao Pieper. Ona može realno biti »slaba i zamagljena kao kod pogana ili snažno svjetlo kao kod kršćana «. Međutim jednako tako i danas smo svjesni da ta ista vjera može prihvatiti predrasude, lakovjernost, može se okrenuti fanatizmu ili netrpeljivosti emancipirajući sebe od »duha mudrosti i razumijevanja, savjeta i duhovne snage, znanja i istinske pobožnosti i svetoga straha $\ll .{ }^{65}$

Zato nam je bilo zanimljivo na tragu Piepera i Newmana promišljati o onome što vjeri daje sigurnost i što je to što ju na neki način čuva od gore navedenih ekscesa. Razum sâm kao proces istraživanja, rasprave, argumenata i zaključivanja očito ne predstavlja tu snagu. Vidjeli smo da se prema Pieperu i Newmanu vjera usavršava poslušnošću, poniznošću i ljubavlju. ${ }^{66} \mathrm{Na}$ analognim temeljima i Pieper i Newman uviđaju da je i sigurnost katoličke vjere apsolutna i savršena sigurnost. Tu tezu grade na djelovanju Božje milosti u životu vjernika. Sigurnost katoličke vjere zasniva se na procesima neformalnoga zaključivanja, počiva na tome da je Bog vječna Istina, onaj koji ne vara i koji ne može biti prevaren i na tome da je upravo on progo-

\footnotetext{
${ }^{62}$ OUS, XII., br. 26.

${ }^{63} \mathrm{Tu}$ se Newman morao suočiti s Lockeovim prigovorima koje je ovaj upućivao prema restrikciji vjerojatnosti, pogotovo kada su u pitanju neke neevidentne relacije između ideja. Tako je Locke smatrao da je upravo vjera čin pristanka koji se ne može izdići iznad vjerojatnosti i zato po njemu ne može imati sigurnost intuicije ili pak demonstracije.

${ }^{64}$ OUS, XII., br. 36.

${ }^{65}$ Isto.

${ }^{66}$ Isto.
} 
vorio čovjeku. Adekvatna zaštita i korektiv takvoj vjeri jedino je i samo ljubav i to iskrena ljubav prema čovjeku, Bogu i cjelokupnoj stvarnosti. Stoga upravo poruka Božje milosti ima za čovjeka oslobađajuću dimenziju jer ga čini slobodnim od svih totalitarizama, fundamentalizama, gdje on misli da sve sam mora učiniti (svojim razumom). Ona opušta čovjeka, daje njegovu životu smiraj i smisao te toliko potrebnu radost, nadu i sigurnost. 
- Š. ŠokČević, Josef Pieper i John Henry Newman o neformalnoj ..., STR. 83-103.

\section{JOSEF PIEPER AND JOHN HENRY NEWMAN ON THE INFORMAL SECURITY OF FAITH}

\section{Šimo ŠOKČEVIĆ*}

Summary: This article is an attempt to interpret Pieper's philosophical treatise On Faith with the help of Newman's thoughts given that Pieper in his treatise refers to certain Newman's theses, but he does not delve deeper into them. Apart from comparing these two authors in the context of philosophical discussion of faith, this paper aims to show that a properly understood faith has a capacity to provide man with that which is most needed today, both in personal and in social context, and that is security. To this end, in four parts, the article presents the meaning of faith, the aspects of informal security of faith and moral predispositions that are necessary for living personal faith in a general cognitive and religious form. In this sense, love imposes itself as the final imperative - the fundamental moral predisposition that protects faith from all abuses, shapes it, gives it consistency, direction, and leads it to the truth.

Keywords: Josef Pieper, John Henry Newman, faith, reason, security, moral predisposition, love.

* Assoc. Prof. Šimo Šokčević, Ph. D., Catholic Faculty of Theology in Đakovo, J. J. Strossmayer University of Osijek, P. Preradovića St 17, P. O. box 54, 31400 Đakovo, Croatia, simo.sokcevic@djkbf.hr 